\title{
A Sociological Perspective on Pidgin's Viability and Usefulness for Development in West Africa
}

\author{
Victoria M. Time and Daniel K. Pryce
}

\begin{abstract}
This essay examines the viability and usefulness of pidgin for development in West Africa. Pidgin in West Africa has endured as a unifying medium of communication among people who do not share a common language. It has been lauded as a neutral language that facilitates trade, commerce, and everyday dealings among people of all walks of life. Some have proposed supplanting English, which is the official language in most of the West African countries where the use of pidgin is prevalent, with either pidgin or some other indigenous language. Contrarians, however, consider pidgin to be a limiting factor, in that, it is a barrier to speaking, reading, and writing standard English, and thus impedes upward mobility. They argue that projecting pidgin or some other indigenous language may create some political backlash, and strife among the people. Using qualitative analysis, we examine this debate from a sociological perspective.
\end{abstract}

Keywords : Pidgin, Development, Literacy, English Pidgin West African

\section{Résumé}

Cet essai examine la viabilité et l'utilité du pidgin pour le développement en Afrique de l'Ouest. Le pidgin en Afrique de l'Ouest a perduré comme moyen de communication unificateur entre les personnes qui ne partagent pas une langue commune. Il est salué comme une langue neutre qui facilite les échanges, le commerce et les transactions quotidiennes entre des personnes de tous horizons. Certains ont proposé de remplacer l'anglais, qui est la langue officielle dans la plupart des pays d'Afrique de l'Ouest où l'usage du pidgin est répandu, par le pidgin ou une autre langue indigène. Les opposants, cependant, considèrent que le pidgin est un facteur limitant dans la mesure où il constitue un obstacle à l'expression orale, à la lecture et à l'écriture de l'anglais standard, ce qui entrave la mobilité ascendante. Ils soutiennent que la projection du pidgin ou d'une autre langue indigène peut créer des réactions politiques négatives et des conflits au sein de la population. En utilisant une analyse qualitative, nous examinons ce débat d'un point de vue sociologique.

Mots-clés : pidgin, développement, alphabétisation, anglais pidgin ouest-africain

\section{https://dx.doi.org/10.4314/contjas.v8i2.1}

Victoria M. Time (vtime@odu.edu) is Professor and University Professor in the Department of Sociology and Criminal Justice at Old Dominion University. She is author of numerous scholarly books and journal articles. Her research interests include, comparative and international justice issues, crimes of culture, theory, and contemporary legal issues.

Daniel K. Pryce (dpryce@odu.edu) is an Assistant Professor in the Department of Sociology and Criminal Justice at Old Dominion University. He was the recipient of the 2017 Dean's Excellence in Research Award and the 2018 Chancellor's Award for Research at North Carolina Central University, his previous employer. His scholarly publications have appeared in Crime \& Delinquency, Criminal Justice and Behavior, Journal of Crime and Justice, Criminal Justice Review, Criminal Justice Policy Review, Journal of Criminal Justice Education, The Police Journal, Security Journal, Journal of Ethnicity in Criminal Justice, Police Practice and Research, Victims \& Offenders, African Identities, Social Science Quarterly, Journal of International Migration and Integration, Virginia Social Science Journal, Police Quarterly, and International Criminology. His co-authored paper that examined the effects of personal and vicarious trauma on African Americans' attitudes toward the police was recently published in Criminal Justice and Behavior. 


\section{Introduction}

We now live in a time when globalization increasingly makes the world smaller, and Africa is no longer forgotten or ignored, as it appeared to have been at one point in history. As we pen this essay, even as Africa now gets news coverage world-wide, its problems remain for the most part unaddressed. Poverty remains Africa's albatross. All but two of the 20 countries with the smallest Gross Domestic Product (GDP) per capita in 2019 were in Africa, and no African country was among those with the largest GDP (Statista.com). 18 African countries as well, make the list of the 25 most illiterate countries in the world (WorldAtlas.com). Discussions about development and prosperity among nations inevitably relate to the future, and how Africa can catch-up with the rest of the world remains an enigma, since the projection is that without substantial economic growth, Africa would be home to the majority of the world's poorest people (CNN. News, 2018).

Language, as Chan (2016) contends, is a necessary ingredient for competitiveness, and as he notes, English as the world's most powerful language is consistently the language used in global economic debates. Chan (2016) lists the 124 power languages based on their importance and their strengths in creating economic, knowledge and media, diplomacy, and other advantages. Unfortunately, pidgin does not make the list. The vitality and importance of pidgin as a conduit to emphasize regional and national integration, and, certainly, the reality of pidgin's messaging role in the socio-linguistic and political growth domestically in the countries where it is spoken cannot be undermined. However, reality in the international sphere, especially as it relates to international corporations and institutions should not be ignored. At one point or the other, the majority, if not all African countries and more importantly, those that form the basis of this discussion have transacted with the World Bank, International Monetary Fund, Bank for International Settlement, or some other international or global institution. The language that was used was not pidgin, since pidgin is not among the languages of use in those institutions (see Chan, 2016). We do not wish to raise any indignation when we wonder aloud how African countries can become competitive in the global economy. The projection is that, if things remain the same, $90 \%$ of the poorest people on earth will be living in Africa (CNN News, 2018). Our focus in this paper is to continue the interchange about the role of pidgin in the social, cultural, political, and economic growth in the countries where the language is spoken.

Literacy remains the most efficacious asset, both personally and nationally, to reverse trends of poverty. Literacy fosters freedom, development, empowerment, and opens up opportunities that enable one or a nation to be competitive in the world. Literacy includes being able to communicate with others, exchange ideas, and negotiate contracts, among other advantages. Therefore, to achieve this end, language becomes the medium. Of the world's languages, English is the most dominant, with about 1.39 billion speakers (WorldsAtlas.com). Colonization introduced Africa to few European languages, with English and French as the most dominant. While English has been the official language of English-speaking countries in West Africa, the push in recent times among some Africans is to depart from the use of English, to make pidgin or some other indigenous language the official language, if not the dominant language in their countries. Admittedly, there are important reasons why pidgin should sustain. Linguists have dominated the debate about the viability and usefulness of pidgin in West Africa. We introduce to the discussion a social science perspective, as we caution the need to carefully consider what has to be done before supplanting English and French as official languages in West Africa. Thus, we address the usefulness of pidgin to West Africa's social, political, educational, and economic development. In other words, we ask the question: would the use of pidgin be more beneficial to Africans and African countries than English and/or French?

We acknowledge that the use of foreign languages (e.g., English and French) as vehicles for development in Africa remains a contested concept, as some scholars have argued that foreign languages' usefulness to the African continent's development has been explored through the lens of problematic modernization theories, which amplify the goals of former colonial masters rather than those of the indigenous people on the continent. Still, our arguments in this paper are not meant to pitch foreign languages against indigenous languages, or project western languages as a route to societal development and social progress in Africa; instead, our focus is on pidgin, a complex blend of foreign and indigenous languages in any African nation where pidgin is an important mode of communication.

\section{What is Pidgin?}

Pidgin is a combination or mix of languages that evolved out of a basic need to communicate with persons who speak different languages where there is an absence of a common medium of communication. Its origins can be traced to the 15th century, when Western Europeans created new settlements in Africa and other regions of the world (Mufwene, 1988). Mufwene (2015: 133) observed that "pidgins are new language varieties that developed out of contacts between colonial nonstandard varieties of a European language and several nonEuropean languages around the Atlantic and in the Indian and Pacific Oceans'. Mufwene added, however, that the use of pidgin in Nigeria, and later Cameroon, may have occurred much later, in the late eighteenth and early nineteenth centuries. In Nigeria, pidgin gained national status because of "its use by popular singers. Their 
performances often combine[d] elements of coastal and west African musical styles, such as highlife and Afrobeat, with African American and Afro-Caribbean styles' (Gaudio, 2011: 231).

Pidgin, sometimes, is referred to as Broken English, Bastard English, Funny English, Kitchen English, and West African Negro English (Barbag-Stoll, 1983), because of its clear deviations from standard grammar, spelling, punctuation, and pronunciation. Africans had to contend with the languages that colonizers, early European merchants, slave traders, and missionaries introduced to the continent, while dealing with the hundreds of languages in a single country. They had to devise ways of communicating with foreigners. This need gave birth to English that assumed indigenous flavorings - "nativization" as Kachru (1986) dubs the process. To be sure, Kachru's use of the term "nativization" relates to the process of infusing English to the phonetics of native languages, and not the need to come up with a way to communicate among multilingual populations. While English and French persist in their standard versions, with occasional new words added, pidgin increasingly receives different colorings within various cultural settings. This explanation supports the argument that pidgin does not have native speakers (Amoako, 1992; Wardhaugh, 1990).

It is common to find pidgin spoken in different ways even within a country. Despite the pluralistic ways in which expressions may be twisted, pronunciation of words or events explained, pidgin endures as a unifying medium of communication within a country, or segments of a country, and such state of affairs leaves supporters to advocate its supremacy. Amoako (1992) notes that, pidgin is undergirded by two criteria: social and structural. The social aspect makes pidgin important because it creates a lingua franca for people who do not share a common language, and the structural component makes pidgin usage fairly easy because of its relatively simplified grammar. Mafeni (1971) and Osoba (2014) discussed how pidgin had permeated broadcast television in Nigeria because of the language's broad appeal to the masses. For this reason, even advertisers have used it consistently to reach citizens with their products. Mafeni (1971) and Osoba (2014) added that the popularity of pidgin transcended broadcast television - it was also found in literary works of Nigerian greats, such as Chinua Achebe. In English-speaking Cameroon, pidgin is widely used as a lingua franca. Citing BarbagStoll (1983), Amoako (1992: 33) noted the importance of Pidgin English in Cameroon:

Though it has little official recognition, it is still an important medium of communication for Cameroon's political, social, religious, and economic life, Amoako (1992) argued that the use of pidgin played an important role in Ghana, as well. That is, pidgin was spoken in many 'educational institutions, work places, airports, seaports, drinking places, markets, on the radio, in popular songs, on political platforms, and on many occasions' (Amoako, 1992: 35). In terms of the pidgin used by students - this is known as Student Pidgin - scholars have argued that the phenomenon is fairly recent, beginning around mid-1965 (Dako, 2002; Huber, 1999; Rupp, 2013). Although the educational authorities in Ghana had assumed that pidgin would "dilute" the mastery of standard English by secondary and university students, Rupp (2013) found that Student Pidgin serves a different role from the standard pidgin spoken across Ghana. Huber (1999) argues that the uneducated speak standard pidgin, whereas students speak Student Pidgin. Standard pidgin is spoken mainly in multilingual urban areas by migrant workers with little to no formal education. Conversely, Student Pidgin, which is infused with local languages (e.g., Twi, Ewe, Ga), remains the domain of secondary and university students who use it to communicate among themselves (Rupp, 2013). Pipkins (2004) noted that Student Pidgin serves as an intra-group language, that is, language spoken by students of the same ethnic group. This harmony of language reinforces the group's social identity in the larger amalgam that Ghanaian universities are composed of. Dako (2002: 54) also argued that Student Pidgin "frees" students from the pressure of speaking standard English at all times, as Student Pidgin did not 'evolve from a communicative need' As a result, Student Pidgin becomes an escape from the pressure associated with the expectation that one must speak standard English on most occasions.

Pidgin English has been used in the Ghanaian media for at least seven decades. There have been a number of programs on radio that used pidgin; and a handful of newspapers, such as the Evening News of the 1950s, had columns that were written strictly in pidgin (Amoako, 1992). While these "outreaches" had targeted the uneducated proletariat, it was soon discovered that Ghanaians who spoke pidgin were in the minority. Over time, these programs no longer produced the economic returns envisaged by the producers, leading to their demise. In their place, producers began making programs in local languages, such as Twi, Ga, and Ewe, and these received far greater reception among the populace than the previous pidgin-themed shows (Amoako, 1992).

Contrarians, however, see pidgin as a limiting factor, in that, it is a barrier to reading, speaking, and writing standard English, hence an impediment to upward mobility. Amoako (1992), for instance, noted that Ghanaians over the age of 40 , as at the time of his study, were not particularly fond of the use of pidgin, believing that it destroyed one's capacity to learn, read, and write standard English. Furthermore, contrarians noted that projecting one language when there are multiple competitive languages, which have not yet received the status of official or national language, is simply a way of cultivating strife and discord within a country.

There is no paucity in the discussion of pidgin as a language, but such richness of literature is dominated by linguists. In this paper, we attempt to examine, through a sociological lens, the main claims raised by both 
proponents and opponents of pidgin in the African context. In that regard, two main questions guide our discussion: (1) Does pidgin promote social and economic advancement? (2) Would replacing English or French as a national language cause national discord or strife?

\section{Does Pidgin Promote Social and Economic Advancement?}

The discussion of pidgin and the sustainability of English as the world's most dominant language has a relatively long history in the literature on languages (Crystal, 2001; Fonyuy, 2010; Gan, 2013; Graddol, 1998; Kouega, 2001; McAthur, 1998; Nielsen, 2003; Ozon, et al., 2017). The debate about the viability and usefulness of pidgin takes stock of the rash of literature that sees pidgin as a unifying language - one that would more rapidly birth greater social and economic growth even in the countries where English, French, or some other Western language is the official language (Atechi, 2011; Fonyuy, 2010; Ndolo, 1989, 1977; Todd, 1982). The U.K. Government, for example, recognized the burgeoning influence of pidgin for unifying large communities in Africa. This led to an announcement in 2015 that the government would-via its largest mouthpiece, the British Broadcasting Corporation (BBC)-invest $£ 85$ million annually to enhance BBC services around the world, including in West Africa where pidgin is frequently spoken by a segment of the region's population. Although this investment would unify pidgin-speaking peoples in Africa around a common lingua franca, the U.K. Government's other goal is to increase the influence and culture of the United Kingdom around the globe, via such services as entertainment, science and technology, health and sports (BBC, 2015, 2017). Noting that pidgin being a mix of English and local languages that allowed people lacking a common language to be able to communicate, and that being widely spoken in Nigeria, Ghana, Cameroon, and Equatorial Guinea, the BBC (2017) emphasized pidgin's wide reach-an estimated 75 million people speak it in Nigeria alone-for its decision to invest in the use of pidgin on its platform. Yet, Kouega (2001) sees pidgin as a culprit in the drop of "proper" written and spoken English in Cameroon, a point later confirmed in an empirical study by Schroder (2003).

Schroder's (2003) study in Cameroon reveals that the vast majority of the 66 interviewees plus the majority of 2000 respondents to her questionnaire were of the opinion that, pidgin breeds poor English, and it is eroding the use of indigenous languages. Amoako's (1992) pioneering empirical investigation of 304 Ghanaian citizens' views of the viability and usefulness of pidgin shows that Ghanaians preferred standard English because it was seen as a "cohesive force," with none of the tens of local languages considered useful replacements for standard English. Indeed, the survey participants believed that pidgin was associated with the uneducated. These viewpoints come into play as some countries debate if pidgin should be made a national language, or an official language. When asked if pidgin hinders one's grasp of English, Laiana Wong, a professor of languages in Hawaii, responds that given how the question is posed, 'it' s obvious that we recognize that pidgin is the subaltern language and English has got superiority' (Wong, 2015: 11). While not contending that to be the case, Professor Wong goes on to state that one who does not speak pidgin in Hawaii may be "handicapped" in terms of communicating with others.

On a larger scale, Nielsen (2003: 203) asserts that English is 'a social and economic mobilizer' (p. 203). In essence, anyone who speaks English has a better chance of obtaining upward mobility not only in the economic sphere, but also in the social standing in a community. The converse is that anyone without a grasp of the English language is likely to remain stagnant, or on a horizontal scale with others similarly situated, or at worst, is likely to be thrust in the abyss of societal class.

Pidgin is not spoken throughout Africa. It is widely spoken in six African countries-Cameroon, Nigeria, Ghana, Liberia, Sierra Leone, and Gambia-and is sporadically spoken in a few other countries primarily in the west coast of Africa. It must be noted that pidgin is not the only language spoken outside of the official languages; there are also indigenous languages/dialects that are spoken within a country (see Table 1).

Table 1: Countries in West Africa Where Pidgin is Most Pervasive

\begin{tabular}{|l|l|l|}
\hline \multicolumn{1}{|c|}{ Country } & \multicolumn{1}{|c|}{ \# Of Local Languages/Dialects } & Official Language (s) \\
\hline Cameroon & 230 dialects (World Atlas) & French \& English \\
\hline Nigeria & 1738 Different linguistic groups & \\
\hline Sierra Leone & 521 languages/dialects (M. Ogunnmodimu, 2015) & English \\
\hline Liberia & 23 languages/dialects (World Atlas) & English \\
\hline Ghana & 30 languages/dialects (World Atlas) & English \\
\hline The Gambia & 250 languages/dialects (Ghanaembassy.nil) & English \\
\hline
\end{tabular}

Language source: World atlas (2019), Graphics maps.com, 2018, Wiki Docs.com 
The first research question of this study is to examine whether pidgin hinders social and economic mobility. Marginalized groups or persons are group of persons relatively deprived of education, wealth, and other trappings of success that a society has to offer, or that a society's wellbeing is measured by. As Murcia (2003) explains, globalization and the global economy have propelled English to the top of most desirable languages, not only because of the vast doors that education in English opens, in terms of employment, but also the respect and admiration that come with the study with the English language. It is this prestige of mastering English that has been characterized as cultural capital, which fosters social mobility (see Bourdieu, 1985), or "social ascension" as Friedrich (2000) prefers to call the process. It is, as Friedrich (2000) explains, the basis why people in far corners of the world study English. Also, based on results of an empirical study that Friedrich conducted in Brazil, the majority of respondents associated English with smartness and worldliness. This line of thought is also evident in Peisker's (2002) study. Findings from Peisker' s study among Croatian migrants of different generations in Australia led to the conclusion that migration to an English-speaking country, and mastering the language, is a prerequisite for a better economic livelihood and social prestige. He unapologetically contends that ' $\cdots$ those who do not realize the importance of English are doomed to be marginalized in the 'global village' of the $21^{\text {st }}$ century' (Peisker, 2002: 152).

The reach and hegemony of English and French, however, across the globe did not happen automatically. The British Council, for example, was established in the 1930s by the U.K. Government to counter propaganda from Communist states like Russia and Fascist nations like Italy and Spain (British Council, n.d.). In addition, the Council's job was to promote British interests and way of life overseas, which was then expected to lead to an appreciation of British foreign policy (British Council, n.d.). Thus, the proliferation of the English language became an important conduit for carrying out the British Council's mandate. Today, the British Council operates in more than 100 countries, with an annual budget of almost $£ 1$ billion. It is worth noting that the English language is not the only language that has advanced internationally. Promoting French interests is Alliance Française Worldwide, a network of more than 800 Alliance chapters operating in 132 countries, including Ghana, Nigeria, and Cameroon. The network was established in 1883 to promote the French language and celebrate Francophone cultures (Alliance Française, n.d.). Originally founded to maintain a strong presence of the French language in former French colonies, its reach has expanded to all parts of the globe, with over 100 chapters operating in the United States alone (Alliance Française, n.d.). This is an important avenue through which France maintains the reach and relevance of the French language. Because many African nations simply do not have the resources to fund such endeavors on a regular basis, it has been difficult to project African languages onto the world stage, or to make them truly international in scope. Thus, the U.K. and France, using their financial power and prestige, have been able to push their languages to the forefront of the world' s most important languages.

This exclusion from the global village occupies Fonyuy's (2010) article in which she explains a "rush" by Francophone parents in Cameroon to have their children study in Anglophone schools, so as to learn English and prevail in the advantages that speaking English bring. This point has also been confirmed by Euromonitor International (2010). The research group explains that English is taking more traction in Cameroon because of its perceived economic development value to both the individual and the country. The same study looked at who is behind the demand for English education in the country and the results are: the individual 52\%; companies 15\%; and the government 78\% (Euromonitor International, 2010).

In Nigeria, as noted by Euromonitor International (2010), of 30 respondents of various companies interviewed, all indicated that prospective employees are expected to have a good or fluent command of the English language. When respondents were asked about the person behind the need for Nigerians to learn English, the result was: the individual 50\%; companies 25\%; and the government 54\% (Euromonitor International, 2010).

English is one of the principal working languages, if not the principal working language, of most multinational companies, like the World Bank, the International Monetary Fund, International Court of Justice, among a plethora of others; service and hospitality industries like hotels, restaurants, in a vast majority of countries; as well as diplomatic relations among countries. Migration from Africa to Europe, the United States, and Australia has seen a rapid increase in the last decade (Crosnoe \& Lopez Turley, 2011; Pryce, 2018; Scheepers, Gijsberts, \& Coenders, 2002), making it necessary to learn English, which is the primary language of the noted countries, for the purpose of integration. The likelihood of success in the new country is, by and large, dependent on how fast one adjusts to the culture, since it has been established that language is an inseparable aspect of culture. It is well documented that non-English speakers in the United States for the most part end up doing menial jobs, which fetch little income, thereby stalling any prospects of upward mobility or personal prestige (Barrett, 2006; Davila, 2008; Johnson, 2002). Such people usually stay marginalized in the United States. In his research on English proficiency and professional mobility among Latinos and Latinas in the U.S., Davila (2008: 359) bluntly states that those without the requisite English proficiency are doomed to engage in 'ethnic work ghettos' or 'ethnically identified occupations'. 
Some African scholars disagree, however, with Africans' preoccupation with European languages, such as English and French, as the primary vehicles of global communication. The celebrated scholar and writer, Ngugi wa Thiong' o, in a detailed interview with the leading German broadcaster, Deutsche Welle [DW] (2018), decried Africans' dependence on European languages, as though the latter were the only ones that bore knowledge and intelligence (Khelef, 2018). wa Thiong' o has instead proposed a different language policy for Africa, what he calls a "triple language policy: Mother tongue, lingua franca and then French or English" (Khelef, 2018). His argument is premised on the belief that a mastery of English, or French, may lead to the false assumption among Africans that knowledge was the preserve of non-Africans. Based on wa Thiong' o's proposal, Ghana or Nigeria, for instance, should place indigenous languages (mother tongues) at the center of communication, followed by pidgin, and then English. According to wa Thiong' o, this order of language use/proficiency would allow Africans "to build confidence, to create investors, discoverers, makers of things because we have the three-language policy" (Khelef, 2018).

\section{Where Does This Leave Pidgin?}

In terms of pidgin, there is no denying that it is a neutral medium of communication by a vast number of people of all ages and socio-economic groups in the countries where it is spoken since it cannot be claimed by a particular ethnic group. In that regard, it breaks barriers. It is a great facilitator of trade and other business and service transactions, especially among people who do not speak a common language. Politicians also find it a convenient medium to disseminate their campaign and reform agendas (Osoba, 2014; Wuteh, 2018). Foremost, it is an inextricable part of culture in those places where the use of the language is entrenched.

Be that as it may, pidgin has its drawback. It is "not a language of power nor of opportunities in the formal sectors' (Ndemanu, 2015: 28), and in the global community. For those who do not aspire to compete on the national stage, or beyond their country's boundaries, they might get by just fine with pidgin. In his discussion about the limits of Nigerian Pidgin, Balogun (2013) opined that, although pidgin had a large presence in music (e.g., the late Fela Anikulapo Kuti sang extensively in pidgin) and entertainment (e.g., soap operas, such as Papa Ajasco), it lacked the formality that standard English possessed. Some Nigerian scholars have suggested that pidgin be adopted as a national language, as it is spoken by about one-half of the population (Elugbe \& Omamor, 1991; Faraclas, 1996). Balogun (2013: 96) disagreed, however, noting that Nigerians "cannot totally lay claim to Nigerian Pidgin as being native to Nigeria'. This position supports Wardhaugh's (1990) argument that pidgin is not native to any country, and national pride might lead some to reject a non-native language as a national language. In addition, Balogun (2013) contends that the orthographical weaknesses of pidgin lowered its appeal as a national language to the educated class. With the absence of typical pronouns (e.g., he and she), the lack of uniform spellings among various ethnic groups, and the absence of tense agreement, Nigerian Pidgin stood little chance of "competing" with standard English, or other more recognized languages in the larger world economy. However, the biggest challenge to Nigerian Pidgin becoming a national language is the federal government's refusal to recognize it as a national language. In spite of its shortcomings, Balogun (2013) argued that Nigerian Pidgin could serve as the nation's lingua franca, if only for its ability to unify a country of 130 million people, who speak well over 400 different native languages (Bamgbose, 1971).

With regard to the concept of marginalization, Dunne (2005) explains: "Marginality is a multidimensional phenomenon in that a given person may be simultaneously integrated with one or more centers while being marginalized from one or more other centers' ( $p .15$ ). A successful businessman who is neither astute in English nor French, may feel included among similarly successful, rich people, but marginalized among elites who garner social prestige because of their command of the English language, and the converse may be true. Noor (2001), for instance, explains a dichotomous way by which social class is viewed within the United States and Asia. In the United States, as Noor explains, social class is mostly determined in terms of wealth, while in Southeast Asia, educational level may determine one's social class.

It is hard to argue against the fact that speaking pidgin alone limits the power of communication, and global competition. The discussion here favors Munandar' s reasoning that English is necessary 'for anyone who wants to communicate beyond the spatial and cultural boundaries of their native country' (2015: 239). In the introduction of this discussion, we alluded to the fact that poverty is still incipient in Africa. For Africa to gradually pull itself out of poverty, it must compete in the global market, and this means Africans must also be grounded in the languages that are necessary for advancement. Indeed, as Eurometer (2010: 58) concludes 'Ambitious Nigerians know that to gain the strongest possible competitive edge in the job market, a good level of spoken and written English is required'

Globally, about 1.27 billion people speak English, and 1.12 billion speak Mandarin (Duffin, 2020). According to Gan (2013), English is the foreign language most Chinese want to learn. It is the language that is mostly taught as a foreign language. Of the 34 languages, each spoken by at least 45 million people, pidgin does not make the list, neither does any other West African language (Ethnologue, 2019). While he does not discuss English in light of prestige or its economic weight, but rather in terms of its functionality in Nigeria, Ogunmodimu 
(2015) nonetheless extols English as Nigeria' s language of literature; it is Nigeria' s archival and library language. It canonizes the nation's history and law' (ibid.: 157). As for pidgin, Ogunmodimu suggests that it should be 'considered a possible informal national lingual franca' (ibid.: 159). Mafeni (1971) credits the proliferation of pidgin to the servants who worked in European households. Mafeni notes that Nigerian pidgin was of two strands: the first, spoken in European households and generally understood by the European masters of servants; and the second, spoken in the larger Nigerian society. Not only does Mafeni support Ogunmodimu's assertion that standard English is an integral part of the Nigerian political, educational, social, and legal environments, but he also adds that many Nigerians were ashamed of using pidgin in a formal setting, due to the realization that pidgin is non-standard English (Balogun, 2013). Indeed, parents and teachers have been known to discourage the use of pidgin by their children and students, respectively, because of pidgin's association with a lower-class status in Nigerian society (Mafeni, 1971).

\section{Would Replacing English or French as a National Language Cause National Strife?}

At times, conflicts and tensions arise in society when power, wealth, and other resources are not evenly distributed. Since Karl Marx's conflict theory, many philosophies and theories have sprouted, explaining domination and strife in society as theories of globalization and world systems, post-structural theories, cultural hegemony, among others. As an inextricable part of culture, the language of a place is the most unifying factor. Issues of discord, at times, arise in multilingual societies when a language by virtue of its use by a dominant majority is a vehicle of operation. This is evident in Cameroon, where the French-speaking majority use not only the language, but their sheer numbers to subjugate English-speaking minorities - a situation which in recent times has led to Anglophone rebellion or civil war. As AllAfrica.com (2019) notes, challenges in mastering the dominant language plus uneven distribution of resources can lead to conflict.

In the countries where pidgin is spoken, pidgin is neither the national nor official language, hence it remains alongside with the multitude of other languages spoken in a country, a neutral medium of communication. Pidgin is not a language that can be claimed by any ethnic group; it is simply a facilitator in bringing people to communicate, who otherwise would not be able to do so. The literature on use of pidgin, as well as Hausa, Igbo, Yoruba and whether any of them should be thrust over other languages in Nigeria, or should replace English as the official language, is rich (see Ndolo, 1989; Ogunmodimu, 2015; Oke, 1969; Oladayo, 2020; Rufai, 1980). The former President of Gambia, Yahya Yammeh, had toyed with the idea of replacing English with one of the indigenous languages of the country. Since his ouster, the idea has not resurfaced. In an article by McCulough and Murtagh (2018) in the Washington Post, it was reported that Sinn Fein was pushing forward the Irish language, although just about $11 \%$ of Northern Irelanders knew the language, hence this measure was rancorous.

The discussion here, centered on whether replacing English or French as a national or official language, is something that can be done without backlash, not only in terms of its viability and usefulness, but also in terms of its acceptability. A language that is projected to a higher status must be widely used and functional. For the language to obtain a national function, it must be used in a "national capacity" in schools, in politics, and in the everyday transactions of the populace. The language must as well serve an international function (Ogunmodimu, 2015), that is it should serve the country in international forums like the United Nations, International Court of Justice, The World Bank, world diplomacy, etc.

For countries thinking of suppressing English, it would mean elevating an indigenous language. Therefore, the question is, which language, given the multitude of languages in a country (see Table 1). As Ogunmodimu (2015) explains, 'To empower an indigenous language as the national language is to, by extension, empower the ethnicity of that chosen language above others' (ibid.: 157). Nida and Wonderly (1971) argued that in order for a language to be projected as a national language, it should be accepted by the masses, because if it is laden with political biases, it would simply be a vessel through which the group that speaks the language extends its dominance, a point Rufai (1980: 28) explores in the Nigerian context. Rufai explains that despite the wide usage of Igbo, Hausa, and Yoruba, the adoption of one over the others may ignite inter-ethnic conflict. Ndolo (1989) also nurtures reservation in projecting one mother tongue over others, in an attempt to suppress or diminish the usage of others, since that could generate bitter consequences. It is to this end that Ndolo thinks pidgin is the better and safer language to project in Nigeria. This premise has dissenters: Oladayo (2020), for instance, in a blog, states that pidgin must "have to rival not only the three major languages but also other over 500 languages in the country for official recognition.'

One cannot ignore the number of wars fought throughout Africa, many of which were triggered by ethnic conflicts (Crary, 1986; Time, 2017). In the Nigerian context, the nation went to war in the 1960s because of the oppression of Igbos by the Hausas in the north of the country. About one million Igbos lost their lives during the civil war (Gaudio, 2011). Although peace would eventually return, yet in this contemporary era, the three largest ethno-linguistic groups continue to view one another with suspicion. Part of this distrust has been blamed on the North's extended hold on political power, starting in the 1960s until the advent of multiparty 
democracy in recent decades. It is, thus, unlikely that any of the majority ethno-linguistic groups in NigeriaHausa, Igbo, and Yoruba-would accept a language other than theirs to be the national language, due to "tribalist" sentiments (Gaudio, 2011). To maintain peace and promote political compromise in the country, Nigeria's leaders after independence continued to use English as the official language. Igbo, Yoruba, and Hausa have about 20 million speakers each, and 50 million Nigerians speak Hausa as a first or second language (Gaudio, 2011). As a result, to have chosen any of these three major languages as the national language would have alienated the rest of the populace and heightened ethnic tensions. Thus, English was retained as the national language while the three major languages were classified as "majority" languages (Gaudio, 2011). To ensure that these "majority" languages are learned by Nigerians, the government requires the languages to be taught in the earliest years of formal education, with English becoming the language of learning in the later years. One notable weakness in this arrangement is that, while the elevation of English over indigenous languages mitigates interethnic tensions, formal education is accessible to just one-fifth of the Nigerian population (Bokamba, 1991). It is for these reasons that Ogunmodimu (2015) proposes a neutral position, as he examines the push to retain English as the official language in Nigeria. He contends that in the context of Nigeria, English is not a foreign language because it is spoken differently with different accents to communicate ideas, so it would be needless to suppress it. He further contends that English is neutral, in that, it is not tribal, hence it would mitigate any chances of strife. Furthermore, he maintained that indigenous languages, including pidgin are not structured, nor cohesive, since there is no standard way of speaking them, and their usage is limited with regard to scope and numbers. Most poignantly, he surmises, there is much to lose if English was abandoned. Given migration, and the pace in which Western education changes society, there is really no sound reason to discard English at this time.

In discussing the plight of English vis-à-vis other languages, Graddol (1998) considered several questions that should be taken into consideration. We discuss them in the African context, be it pidgin or other indigenous language:

- $\quad$ How many speakers of the language would there be in the next few decades, say by 2050?

- What role would the language play in people's lives? Would the language simply be used to

facilitate trade? Or would it be used as a source of cultural enrichment?

- In the economic sphere, how would pidgin promote a nation's fiscal health?

- Would the language be one that would be promoted by other countries?

- What role would the language have in helping industrialize new economies?

In answering the questions posed by Graddol, we situate our discussion in Omoniyi' s (2006) argument that " $t$ ] he contemporary relevance of English in the [West African] region is ensconced in the language policies of the Anglophone states and the anchorage of the regional economy to a global one for which English remains the most important medium of transaction' (ibid.: 181). Omoniyi (2006) employs a powerful example in the area of education, to explain why the English language remains entrenched as the national language of Englishspeaking West African countries (see Table 2 below).

Table 2: Country population and \# who speak the official language

\begin{tabular}{|l|l|l|l|}
\hline Country & Population & Engl ish & French \\
\hline Cameroon & $24,000,005$ & $(16 \%)$ & $83 \%$ \\
\hline Nigeria & $190,900,000$ & $79,000,000$ & \\
\hline The Gambia & $2,092,731$ & 41,000 & \\
\hline Sierra Leone & $7,557,000$ & $4,900,000$ & \\
\hline Liberia & $4,732,000$ & $3,100,000$ & \\
\hline Ghana & $28,830,000$ & $18,000,000$ & \\
\hline
\end{tabular}

Population source: World Bank (2017), World Factbook, 2018

Omoniyi (2006) identifies a number of "domains" of English usage, including administration (local, state and federal governments), examinations, university entrance, job interviews, civil service promotion tests, aptitude tests, education (medium of instruction as well as curriculum subject), and commerce. In terms of education, Omoniyi (2006) notes the role English plays in the work of the West African Examinations Council (WAEC)-a group whose membership spans several West African countries-in administering pre-university exams to secondary school students. In effect, WAEC, which conducts its business and examinations primarily in English, remains a "gatekeeper" for transitioning from secondary school to the university, where the foundations for higher economic success are firmly laid. The authors of this manuscript had themselves, undoubtedly, gone through WAEC's strict protocols for advancement in the field of education. With the mastery of English tied to much larger socio-economic success outside of West Africa, many leaders and governments of West African 
nation-states do not believe that replacing standard English with an indigenous language, or pidgin, would serve the best interests of their nations and citizens. While international trade and transaction are expected to be carried out in standard English, the latter also serves as a language of choice, alongside other domestic languages and pidgin, for internal trade and market activity. Thus, the use of standard English serves a similar function as local languages/pidgin as far as trade is concerned.

In addition, we note that Western European nations, the United States, Canada, Australia, New Zealand, and other English-speaking powerhouses simply do not regard pidgin as an equivalent of standard English. Thus, it is unlikely that West African nations' adoption of pidgin would make them competitive globally. Moreover, West African leaders themselves do not necessarily consider pidgin a proper medium of communication (Mafeni, 1971). This explains why the leaders are not likely to promote and elevate pidgin to the status of a national language.

\section{Conclusion}

The provenance of West African Pidgin English can be traced to the arrival of European settlers in Africa, dating back to the $15^{\text {th }}$ century. As these Europeans came into contact with the natives who did not speak English, a new language (pidgin) developed to enable the foreigners communicate with the natives. In West Africa, pidgin did not replace local languages: instead, it has served as a medium of communication among locals who speak different languages, as well as a medium of communication between natives and non-indigenous people. This has been the case in Nigeria (Mafeni, 1971), Cameroon (Todd, 1984), Liberia (Singler, 1987), and Ghana (Amoako, 1992; Dako, 2002; Huber, 1999; Pipkins, 2004). In Ghana, pidgin is not spoken by only the uneducated: a different version, Student Pidgin, has been in use by secondary and university students for the last several decades (Dako, 2002; Rupp, 2013). This development shows that pidgin plays a fairly prominent role in communication among Ghanaians. As Mufwene (1988) asserts, pidgin's importance in West Africa cannot be understated, as it competes with native languages and equally serves to keep interactants engaged, be it in an office space or public space. It is its usefulness in the global village that raises questions.

It may appear that we are against the use of pidgin as a national language in any of the African countries noted in this paper, nonetheless, that is not the case at all. In this paper, we have attempted to make an argument for the primacy of English, or French, as the official lingua franca in African nations in which pidgin use is fairly widespread. Our position, however, is based on the fact that the winds of power currently blow in favor of Western nations that have dominated global trade and commerce, since they have used their national languages to maintain their political and economic hegemony, and most likely the destinations of African migrants ostensibly in search of "greener pastures." We would not have argued in favor of English as the official language in places such as Ghana and Nigeria if those countries' indigenous languages occupied stronger positions on the axes of power across the globe, but that is not the case presently. Moreover, addressing the etiology of the power imbalance between Western and African nations is not our primary argument; rather, it is beyond the scope of this paper. We have simply attempted to situate our argument for the primacy of English in African countries in the economic and social advancements that the mastery of English might provide for both Africans and Africa. To this end, we hope that our paper would engender a new round of scholarly discussions about the importance of language in any nation, especially those in Africa. 


\section{References}

(Alliance Française (n.d.). Our history: Origins of Alliance Française. Retrieved from https://www.afsf.com/aboutus/our-history/.

Amoako, J. K. Y. B. (1992). Ghanaian Pidgin English: In Search of Diachronic, Synchronic, and Sociolinguistic Evidence [Doctoral dissertation, University of Florida]. Retrieved from Proquest Dissertations and Theses database.

Atechi, S. (2011). Is Cameroon Pidgin flourishing or dying? An attempt to reconcile conflicting reports onfunctions and status of Cameroon pidgin English. English Today, 27(3), 30-34.

Balogun, T. A. (2013). In defense of Nigerian pidgin. Journal of Languages and Culture, 4(5), 90-98.

Bamgbose, A. (1971). The English Language in Nigeria. In J. Spencer (Eds.), The English Language in West Africa (pp. 35-48). London: Longman.

Barbag-Stoll, A. (1983). Social and Linguistic History of Nigerian Pidgin English: As Spoken by the Yoruba with Special Reference to the English Derived Lexicon. Tubingen: Stauffenberg Verlag.

Barrett, R. (2006). Language, Ideology and racial inequality: Competing functions of Spanish in an Anglo-owned Mexican restaurant. Language and Society, 35(2), 163-204.

Bokamba, E. G. (1991). West Africa. In J. Cheshire (Eds.), English Around the World: Sociological Perspectives (pp. 493-508). Cambridge: Cambridge University Press.

Bourdieu, P. (1991). Language and Symbolic Power. Cambridge, Mass.: Harvard University press.

BBC (2015). BBC World Service gets a boost from government. Retrieved from https://www.bbc.com/news/entertainmentarts-34902244.

BBC (2017). BBC starts Pidgin digital for West Africa audiences. Retrieved from https://www.bbc.com/news/world-africa40975399 .

British Council (n.d.). Why the British Council was created. Retrieved from https://www.britishcouncil.org/aboutus/history.

Chan, K. (2016). These are the most powerful languages in the world. World Economic Forum. Retrieved From https://www.Weforum.org/agenda/2016/12/these-are-the-most-powerful-languages-in-the-world.

CNN. Breaking U.S. and World News. Nigeria overtakes India in extreme poverty ranking-CNN. Https:www.cnn.com/2018/06/26/Africa/Nigeria-overtakes-India-extreme-poverty-int/index.html.

Crary, D. (1986). African Continent tormented by tribal conflicts: Problem has triggered wars, toppled governments, and wrecked courtships, Los Angeles Times, March 23, 1986. http://www.Latimes.com. Retrieved, 5, 10, 2020.

Crosnoe, R., \& Lopez Turley, R. (2011). K-12 Educational Outcomes for Immigrant Youth. The Future of Children, $21(1), 129-152$.

Crystal, D. (2001). Language Death. Cambridge: Cambridge University Press

Dako, K. (2002). Student Pidgin (SP): the language of the educated male elite. Research Review, 18, 53-62.

Dunne, R. (2005). Marginality: A conceptual extension. In R. Dennis (ed.) Marginality, Power, and Social Structure: Issues in Race, Class, and Gender Analysis. 11-27. Amsterdam: Elsevier.

Duffin, E. (April 3,2020). The most spoken language worldwide in 2019. Statista. Https://www.statista.com/statististics/266808/the-most-spoken-languages-worldwide.Retrieved 5/18/2020.

Elugbe, B. O., \& Omamor, A. P. (1991). Nigerian Pidgin: Background and Prospects. Ibadan: Heinemann Educational Books.

Ethnologue (2019, 23 $3^{\text {rd }}$ edition). SIL International.

Faraclas, N. G. (1996). Nigerian Pidgin. London: Routledge.

Fonyuy, K.E. (2010). The rush for English education in urban Cameroon: Socio-linguistic implications and prospects. English Today. 26(1), 34-42.

Friedrich, P. (2000). English in Brazil: Functions and attitudes. World Englishes, 19, 215-223.

Gan, Z. (2013). Understanding English speaking difficulties: An investigation of two Chinese populations. Journal of Multilingual and Multicultural Development, 34:3, 231-248. 
Gaudio, R. P. (2011). The Blackness of “Broken English,” Journal of Linguistic Anthropology, 21(2), 230-246.

Graddoll, D. (1998). The Future of English? A guide to forecasting the popularity of the English Language in the $21^{\text {st }}$ century. The British Council. The English Company (UK) LTD. www.d1watxts1xzle7.cloudfront.net. Retrieved, 4/12/2020.

Huber, M. (1999). Ghanaian Pidgin English in its West African context. Amsterdam, Netherlands: John Benjamins. Johnson, F. (2002). Speaking culturally. Thousand Oaks, CA: Sage Publishing.

Kachru, B.B. (1986). The Alchemy of English: The Spread, Functions, and Models of Non-native Englishes. Champaign, Il: University of Illinois Press.

Khelef, M. (2018). Ngugi wa Thiong'o: African languages need to talk to each other. Retrieved from https://www.dw.com/en/ngugi-wa-thiongo-african-languages-need-to-talk-to-each-other/a-44297656.

Kouega, J.P. (2001). Pidgin facing death in Cameroon. Tetralingual. http://www.terralingua.org/DiscPapers/DiscPaper17.html. Retrieved, 4/2/2020.

Mafeni, B. (1979). Nigerian Pidgin English. In J. Spencer (Eds.), The English Language in West Africa (pp. 95112). London: Longman.

McCulloch, A., and Murtagh, C. (2018). Post-Northern Ireland is in crisis because of a dispute over language, http://www.WashingtonPost.com/monkey-cage/wp/2018/03/02/northern-ireland-is-in-crisisbecause-of-a-squabble-over-language. Retrieved, 5/3/2020.

McArthur, T. (1998). The English Languages. Cambridge: Cambridge University Press.

Mufwene, S. S. (1988). English Pidgins: Form and Function. World Englishes, 7(3), 255-267.

Mufwene, S. S. (2015). Pidgin and Creole languages. In James D. Wright (Eds.), International Encyclopedia of the Social \& Behavioral Sciences (Vol. 18, pp. 133-145). Oxford: Elsevier.

Munandar, I. (2015). How does English Language Learning Contribute to Social Mobility of Language learners? A/-Ta Lim, 22 (3). Doi. http://dx.dio.org/10.15548/jt.v22i3.157.

Murcia, M. N. (2003). English is like the dollar: hard currency ideology and the status of English in Peru, Journal of World Englishes, 22(2), 121-142.

Ndemanu, M. T. (2015). Ebonics, to be or not to be? A legacy of trans-Atlantic slave trade. Journal of Black Studies. 46(1), 23-43.

Ndolo, I.S. (1989). The case for promoting the Nigerian pidgin language. The Journal of Modern African Studies. 27(4), 679-684

Nida, E. and Wonderly, W. (1971). Communication roles of languages in multilingual societies. In Hymes D. (ed) Language in Culture and Society: Reader in Linguistics and Anthropology, pp. 57-74.

Nielsen, P.M. (2003). English in Argentina: A sociolinguistic profile. World Englishers. 22(2), 199-209.

Noor, R. (2001). Contrastive rhetoric in expository prose: Approaches and achievement. Journal of Pragmatic, $33(2), 255-269$

Ogunmodimu, M. (2015). Language policy in Nigeria: Problems, prospects and perspectives. International Journal of Humanities and Social Science, 5(9), 154-160.

Oke, D.O. (1969). Toward a Homogenizing Language Policy, University of Ife, Ile-Ife.

Omoniyi, T. (2006). West African Englishes. In B. B. Krachu, Y. Krachu, and C. L. Nelson (Eds.), The Handbook of World Englishes (pp. 172-187). Blackwell Publishing Ltd.

Osoba, J. (2014). The use of Nigerian Pidgin in political jingles. Journal of Universal Language.15(1), 105-127.

Ozon, G. (2017). The spoken corpus of Cameroon Pidgin English. World Englishes. 36(3), 427-447.

Peisker, V.C. (2002). Croatians in Western Australia: Migration, language and class, Journal of Sociology, 38 (2), 149-166.

Pipkins, D. (2004). Pidgin! Make we hear you speak, Make we know why chaw students dey luv you. African Diaspora ISPs. 57. Retrieved from https://digitalcollections.sit.edu/african_diaspora_isp/57.

Pryce, D. K. (2018). U.S. Citizens' Current Attitudes Toward Immigrants and Immigration: A Study from the General Social Survey. Social Science Quarterly, 99(4), 1467-1483. 
Rufai, A. (1980). The question of a national language in Nigeria, Mooland-Spingarn Research center, Howard University, Washington, D.C. Google Scholar.

Rupp, L. (2013). The function of Student Pidgin in Ghana. English Today, 29(4), 13-22.

Scheepers, P., Gijsberts, M., \& Coenders, M. (2002). Ethnic exclusionism in European countries: Public opposition to civil rights for legal migrants as a response to perceived ethnic threat. European Sociological Review, $18,17-34$.

Schroeder, A. (2003). Cameroon Pidgin English: A means of bridging the Anglophone-Francophone division in Cameroon? AAA: Arbeiten aus Anglistik und Amerikanistik, 28(2), 305-327.

Singler, J. (1987). The city, the Mesolect, and Innovation. Journal of Pidgin and Creole Languages, 2, $119-147$.

Statista.com. The Top 20 countries with the largest gross domestic product (GDP) in 2019. https://www.statista.com/statistics/268173/countries-with-the-largest-gross-domestic-product-gdp. Retrieved, $4 / 15 / 2020$.

Time, V. (2017). Women's Social and Legal Issues in African Current Affairs: Lifting the Barriers. Lanham: Lexington Books.

Todd, L. (1984). Modern Englishes: Pidgins and Creoles. London: Basil Blackwell.

Todd, L. (1982). English in Cameroon: Education in a multilingual society. In John Pride (ed.). New Englishes. Rowley MA: Newbury House, 119-137.

Wardhaugh, R. (1990). An Introduction to Sociolinguistics. Cambridge, MA: Basil Blackwell.

Wong, A. (2015). De-stigmatizing Hawaii's Creole Language: Why the decision to recognize Hawaiian pidgin English in U.S. census surveys matters. The Atlantic. https://www.theatlantic.com/education/archive/2015/11. Retrieved, 4/6/2020.

WorldAtlas.com. 25 most illiterate countries. https:// www.worldatlas.com/articles/the-lowest- literacy-rates-in-theworld.html. Retrieved, 4/15/2020.

WorldAtlas.com. World's most dominant language. https://www.google.com/search?q=world\%27s+dominant+language\&ie=UTF8\&oe=UTF-8\&hl=en-us\&client=safari. Retrieved, 4/15/2020.

Wuteh, V. (2018). The status of Pidgin English in Cameroonian Tower of Babel: An overview of the linguistic landscape of Cameroon which calls for the recognition of Cameroonian pidgin English as an official language. English Today.34(1): 20-25. 